\title{
Queering Girlhood
}

\author{
Barbara Jane Brickman
}

\section{$\cos 80$}

In their ${ }^{1}$ new groundbreaking study reviewed in this special issue, The Trans Generation: How Trans Kids (and Their Parents) are Creating a Gender Revolution (2018), sociologist Ann Travers details the experiences of transgender children in the US and Canada, some as young as four years of age, who participated in research interviews over a five-year period. Establishing a unique picture of what it means to grow up as a trans child, Travers offers numerous examples of daily life and challenges for children like, for example, Martine and Esme, both of whom sought to determine their own gender at an early age: Martine and her family recount how at the age of seven she responded to her upcoming appointment at a gender clinic by asking if the doctor would have "the machine where you walk in as a boy and walk out as a girl," while Esme's story begins in preschool and leads to the care of a "trans-affirmative doctor" (168) from the age of six and the promise of hormone blockers and estrogen at the onset of puberty. Although Travers's work is devoted to and advocates for trans children as a whole, its implications for our understanding of and research into girls and girlhood cannot be understated. What does it mean to "walk out" of that machine in the doctor's office "as a girl?" What happens when you displace the seemingly monumental onset of puberty from its previous biological imperatives and reproductive futures? How might feminist work on girlhoods, which has sought to challenge sexual and gender binaries for so long, approach an encounter with what Travers calls "binary-conforming" or "binary-identifying" (169) trans girls or with the transgender boys in their study who, at first, respond to the conforming pressures of adolescence very similarly to cisgender girls who will not ultimately transition away from a female identity?

These questions provoked by the fairly recent recognition of transgender young people, however, mark only the latest entry in an ongoing debate about the ways in which the queer girl might effect a redefinition of girlhood itself. Over ten years ago, Marnina Gonick confronted the burgeoning field of girls' studies with a foundational question, "Are queer girls, girls?" (2006: 122). In 
the intervening years, girls' studies has emerged as an increasingly acknowledged, influential, and diverse area of academic discourse, yet much of the scholarship remains distressingly unable (or unwilling) to dislodge girlhood from its (hetero)normative grounds. Although we have perhaps come a long way from a place where, as Susan Driver described it, the "pairing of the words queer and girl" was "virtually unthinkable" (2007: 28), the enduring centrality of a white, able-bodied, Western heteronormative girlhood continues to plague critical work on girls and girl cultures. Therefore, as the call for this issue suggested, it seeks to challenge such persistent normalizing by bringing the queer girl from the margins to the center of girls' studies.

Too often, when they do appear in popular representations or public discourse, queer girls are characterized as a problem to be solved, being in a phase that they will (or must) grow out of, or a minor point in a larger debate about young female sexuality. Conversely, in considerations of queer youth, they again find themselves marginalized or silenced by a seemingly inescapable focus on their male peers. Theirs are, in short, voices we too rarely hear and experiences that are too rarely figured. In response, and in line with recent work by Sarah Projansky, who acknowledges the "dominance of whiteness, femininity, and heteronormativity" (2014:9) in representations of girlhood and who, therefore, seeks to shift our critical focus to girls typically marginalized from this normative center or to "various alternative girls—often girls of color and/or queer girls" present in our media but too often overlooked in feminist media studies, the contributors to this volume re-cast girlhood itself as defined and redefined by the queerness and queer girls who have been, in Projansky's terms, "right there, right in front of us" (17) all along. Drawing on various disciplinary perspectives, the articles in this special issue foreground the experiences and representations of queer girls in media, literature, transmedia franchises, contemporary global cultures, and historical accounts, as well as consider the impact of queer girl cultures and girl producers on our changing understanding of girlhood. My central goal, as guest editor of this special issue, was to offer as diverse a range of approaches to studying girlhood as possible and, thereby, to suggest how focusing on queer girls is still such a necessary intervention in so many fields and areas of feminist and cultural criticism.

\section{Queer Girls, From Gothic Horror to Contemporary Tokyo}

Announcing from the opening article the special issue's objective to demonstrate how queerness and the queer girl might necessitate a redefining of 
girlhood itself, Robyn Ollett's "Miles away from Screwing? Queer Gothic Girlhood in John Harding's Florence and Giles," brings together the notion of the queer child and the tradition of the Gothic to argue for the radical potential of queer girlhood. Ollett examines Harding's (2010) contemporary re-envisioning of Henry James's classic Gothic tale The Turn of the Screw (1898), which has drawn intensive critical attention over the years, particularly from psychoanalytic and queer critics, as an opportunity to establish the subversive force of the queer Gothic girl whose desires can not only transform language and narrative but also bridge a divide between feminist and queer critical perspectives. Inspired by the queer feminist ethics set forth by Lynne Huffer, Ollett's close reading of Harding's young anti-heroine, Florence, seeks to further a "knitting together" of "disparate ideas in queer theory and feminism" through this unique figure of a "queer girlhood which is both derivative and transformative." Finding a pathway between theorists as diverse as Terry Castle, Barbara Creed, Ellis Hanson, and Leo Bersani, Ollett argues for this queer girlhood as a "whole Other thing" capable of bringing together, productively, both feminist and queer perspectives.

Similarly placing these two critical perspectives in conversation, but using an historical approach, Amanda Littauer's article, "Your Young Lesbian Sisters': Queer Girls' Voices in the Liberation Era," pursues questions of identity, agency, and expressive authority so central to feminist girls' studies but develops them through the close documentation of queer historiographical methods. Through the voices emerging from personal letters and essays written by teenage girls in the 1970s and 1980s, Littauer reveals a sometimes raw and authentic picture of the desires, confusion, pleasures, and impressive political activism of same-sex desiring girls in this insufficiently explored period. While many of these young writers and activists recognized their comparative advantages in growing up in the post-liberation era, with adult homophile organizations to approach and (slowly) changing attitudes toward non-normative sexual and gender identities, Littauer's work also presents an enduring sense of isolation and confusion felt by these girls, as well as a real disappointment in "what they saw as adult lesbians' ageism, caution, and neglect" in response to their appeals for camaraderie, advice, or support. Littauer's historiographic work here offers an enlightening glimpse into the feelings, experiences, and political sophistication of queer girls nearly half a century ago, but the intergenerational tension and the semi-autonomous adolescent frustrations remain all too familiar.

The next two articles continue in this vein of presenting the voices and experiences of queer girls themselves, using ethnographic approaches to 
queer female experiences in contemporary Japan and in pop culture fandom. Marta Fanasca's article, "Crossdressing Dansō: Negotiating Between Stereotypical Femininity and Self-expression in Patriarchal Japan," draws from interviews with fourteen dansō informants to explore the childhood and adolescence of these queer youth who work as escorts in contemporary Japan. Fanasca explores how danso (identified as "female-to-male crossdressers") negotiate their non-normative gender identity throughout their youth, particularly how they respond to, or cope with, the heteronormative edicts of the dominant, patriarchal culture as it pressures them to suppress a masculine identification. Although the entertainment work done by dansō is a relatively recent development in Tokyo, Fanasca's study follows her informants back through their childhoods to consider how they formed and protected their queer selves growing up. Not recognizing themselves as toransujend $\bar{a}$ (transgender), danso construct their own "male identity through the linguistic, behavioral, and aesthetic practices that define masculinity in contemporary Japan" and defy simple notions of normative sexuality and gender. Refusing to define themselves as either male or female and embracing various sexual identities, the danso interviewees in this article truly expand even established notions of queer girlhood.

Moving out to the world of international pop music and female fan practices, Hannah McCann and Clare Southerton's work considers the queer potential in fans (known as Directioners) of recent boy band phenomenon, One Direction. Their article, "Repetitions of Desire: Queering the One Direction Fangirl," challenges both critical and popular notions of the muchmaligned fangirl of popular culture, particularly of male pop idols, who has been so often represented as both hysterical and fixated, and duped by the machine of consumer culture and whose desires have been consistently framed in terms of heterosexual romance. However, the fangirls given voice in this article, members of a subgroup of Directioners known as Larries who base their fandom around a possible relationship between two of the band members, Harry Styles and Louis Tomlinson, employ queer reading strategies and group practices that create unique feelings of intimacy, communal identity, and queer desire. Drawing from one-on-one interviews as part of a digital ethnography project with Larries on Twitter, McCann and Southerton present a direct account of queer space-making on social media and through other fan activities, transforming the accepted heteronormative notions of the fangirl, who in this (relation)shipping community, conversely, expresses "complex forms of desire that appear to belong more to the collective" than the individual and who queerly demands a space for desiring "desire itself." 
Lucy Baker's article on the DC Super Hero Girls, "I'm No Princess: Super Hero Girls Together," likewise considers the consumption practices of girls, but broadens out the discussion to consider many other aspects, texts, and objects within this popular transmedia franchise that offer a queered version of girlhood. From the comics and their on-line ephemera, such as short stories and biographies, to multimedia texts like films and games and, of course, dolls and other associated merchandise, the collection of objects in the DC Super Hero Girls universe, Baker argues, is not only vast but also tied to adult canonical material with more overt queer content, creating a kind of continuum for queer reading practices by fans, especially older girls. Locating a subversion of normative femininity or at least a complex signification of gender and a space for queer play by consumers, Baker proposes that the various elements of the Super Hero Girl franchise revise traditional comics by allowing for its young female characters to "inhabit a liminal proto-queer space between homosocial/gender non-conforming and lesbian," which certainly differentiates it from franchises central to princess culture. Moving away from the hyper-feminine, unrealistic bodies and heteronormative plotlines of other girls' media texts, the franchise offers a place for queered (and queering) heroes.

Closely reading another influential area of popular culture, Young Adult (YA) fiction, in perhaps its most favored current genre, dystopian narratives, Miranda A. Green-Barteet and Jill Coste's article, "Non-normative Bodies, Queer Identities: Marginalizing Queer Girls in YA Dystopian Literature," brings attention to the dearth of queer female protagonists in YA dystopian fiction and argues, through a careful examination of two popular examples, Scorpion Rules (2015) and Love in the Time of Global Warming (2013), that even when queer female protagonists appear, they are ultimately subsumed back into heteronormative frameworks. Featuring bisexual female protagonists expressing various queer desires and a number of other queer characters, including a sexually assertive female love interest, a transgender love interest, and queer male friends, both novels seem to assert an empowered queer girlhood at the center of their world-reforming dystopian plots, yet ultimately, as Green-Barteet and Coste argue, they marginalize this queerness by equating it with "non-normative bodies" and then erase it in service of the concluding heteronormative status quo. While this opening up of the dystopian YA fiction to the presence of a strong, queer female agency should not be discounted, the novels' potential critique of the genre and of dominant culture falls short for these contributors who call for a continuing expansion of definitions of girlhood. 
The final article in the special issue, Whitney Monaghan's "Not Just a Phase: Queer Girlhood and Coming of Age on Screen," concludes with perhaps a more encouraging development in the project of queering girlhood. In a number of recent American independent films, Monaghan finds not only an increased visibility of queer girls but also a rejection or revision of previous dominant tropes that served to marginalize or contain queer girlhood within fleeting temporal frameworks. Considering four feature films made since 2010_Pariah (2011), Mosquita y Mari (2012), First Girl I Loved (2016), and Princess Cyd (2017)—Monaghan evaluates them in terms of her own previous claims that all too often queer female experiences in popular media are represented as a "passing phase of girl's adolescent development" and, thereby, disregarded as merely a temporary divergence from "a linear path toward heteronormative adulthood," and discovers that these new films, instead, offer a more complex and varied interplay between queerness and girlhood. Rather than confining queerness to a generic coming out plot or to "just a phase" in a girl's normative trajectory, these films broaden out their narratives to consider questions of consent, familial obligations, and the significance of friends, as well as diversifying the representations of queer girlhood on screen.

Monaghan concludes her article by noting that all the films under discussion found acclaim and were exhibited internationally at LGBTQ+ film festivals, which, of course, points to the key role these types of venues play for those queer texts that challenge traditional forms of representation and normative ideas of girlhood. Following Monaghan's article in recognition of the importance of these venues, is Andrew Scahill's review in which he documents the creative works of queer girls (and boys) that were presented at the Youth Media Program of the 2018 Fairy Tales Film Festival in Calgary. Scahill reviews exciting new short films by five young filmmakers, who were invited to sit down with him to discuss their process, inspirations, collaborations, and thematic concerns as queer artists. This review allows us an invaluable chance to consider, as Scahill asks the filmmakers, what stories would queer girls (and boys) "tell about their own lives? What stories would they share with one another?" Finally, this special issue ends where my introduction began with a review of Ann Travers's The Trans Generation: How Trans Kids (and Their Parents) are Creating a Gender Revolution. Lucy Curzon's review of Travers's book points this journal and scholars towards future work on, and understandings of, girlhood that might be more inclusive and even transformational. 


\section{Conclusion: The Secret Life of Girls}

One of the issues that Travers raises in their study and that threads through many of these articles, is the concern that queerness is viewed or constructed as "just a phase" (2018: 29) for girls and, therefore, their adolescence is experienced as a time of severe normalizing pressures. ${ }^{2}$ The special temporality of girlhood, then, becomes an imprisoning trap or even an existential threat to queer sexuality, gender variance, or many other girl subjectivities that refuse to conform. In this light, girlhood can be viewed as a kind of crucible for queerness, which makes it even more imperative that girls' studies takes into account the lives, experiences, and representations of queer girls. Yet, conversely, queer girlhood might also serve as a crucible for feminist scholarship as well, as the scholars I cited earlier-Gonick (2006), Driver (2007), and Projansky (2014) — have argued. Queer girlhood has the potential to prompt feminist scholars to reexamine their own methods and object of study and to endeavor, as Mary Celeste Kearney implores in her introduction to Mediated Girlhoods: New Explorations of Girl's Media Culture, to "subvert the white, heterosexual, middle-class, Western, and presentist framework that continues to dominate girls' media studies and thus public perceptions of girls' media culture" (2011: 11), a project she views as vital to further examinations of girlhood.

Elsewhere, like Projansky (2014), I have argued that the queer girl has always been "right there, right in front of us" (17), for example, smack dab in the middle of girl's "bedroom culture" (Brickman 2018: 64) as represented in mass media or created by female fans, and it is the responsibility of feminist scholars to recognize her there. Indeed, for far too long, scholarly examinations of girlhood and girls' cultural practices have "neglected the queer potential and practices of girls" (Brickman 2016: 444), but more than that, I wonder, have we neglected a foundational interrelation between these two concepts-queerness and girlhood? Might one argue that "queerness" has circled around "girlhood" and resided at the margins or even foundations of its very definition all along? Inspired by Kathryn Bond Stockton's assertion of the "queer temporalities haunting all children," who can only be "not-yet-straight" within a presumed innocence "merely approaching while crucially delaying ... the official designation of straight sexuality" (2009: 7, emphasis added), I want to propose a queerness haunting if not all girls, then certainly central conceptions of girlhood.

Several years ago, during a long commute, I found myself transfixed by a National Public Radio series called "The Hidden World of Girls." For this 
radio project, the Kitchen Sisters (Davia Nelson and Nikki Silva) set out to explore the often-neglected stories of girls' lived experience: stories of "coming of age, rituals and rites of passage, [and] secret identities," which girls (and women) all over the world could share by leaving a voicemail message, by constructing their own responses on YouTube, Twitter, or Facebook, or by answering a specific call by the series, for example, for photographs of intimate diary entries (Kitchen Sisters 2010). The episode that I heard, centering on science fiction writer Pat Cadigan's recollection of one special friendship, fit perfectly into this model of girls' intimate identities in a romanticized "hidden world." Cadigan described an "involved secret life" she created with her friend Rosemarie from elementary school onward in which they lived as twins from Venus who had "secret exclusive contact with the Beatles," resulting in their advising the Fab Four on their music and "other important matters." Graced with super-powers and famous on Venus, the twins even used a "body changing machine" to shapeshift (and, of course, gender shift) into the Beatles and round out recording sessions for them. Predictably, the friends eventually grew apart, but Cadigan's description of their imaginative life and relationship strikes me as extraordinarily meaningful: "this complex double life lasted from 1963 to a time when we should have outgrown it, except we were having too much fun." Condensed into this short radio program on girls, we have all the markers of a defining queerness, set to the strange sound effects of 1950s science fiction classics like The Day the Earth Stood Still (1951), a secret, intimate (and imaginative) life that feels "double" and even shameful (in their protracted attraction to it), but remains so difficult to let go of and mourned when it is gone because of its empowering fluidity of identity, its shared bliss, and its "secret" importance for their coming of age.

What I would stress here, of course, is that Cadigan's story is not offered as a description of queer girlhood; it is, instead, a relatively recognizable, even common, tale of female maturation in the West. With the notable exception of the "body changing machine," which so beautifully presages Martine's invention, mentioned in Travers's book, with which I began, this story has the hallmarks of so many previous accounts of girls' supposed "culture of the bedroom," as Frith (1978: 64) designated it over forty years ago. Sequestered alone but more typically with other special female friends in the bedroom, the girls of this commonplace description create a "double life" in which they write secrets in their diaries or share hushed confessions with each other, invent strange stories or shared identities, daydream, fixate on pop idols, and possess an unsettled, and unsettling, sexuality. Indeed, 
centered in an intimate, closeted queer space, girl culture remains disturbingly, at times defiantly, to use Stockton's terms, "not-yet-straight" (2009: 7). As I have argued elsewhere, it is perhaps only "a phobic response to this queerness" at the heart of girl culture that has prevented its recognition in scholarship and popular accounts. My hope with this special issue of Girlhood Studies; An Interdisciplinary Journal, is that we might re-view or even redefine girlhood and girl culture as that "empowering queer space" (Brickman 2016: 447) that took Cadigan and her friend to Venus and back, and not mourn its loss or relegate it to being "just a phase" in a normative developmental path, but celebrate it and elaborate on it, in all its queerness.

\section{Acknowledgements}

I am incredibly grateful to editor-in-chief Claudia Mitchell and managing editor Ann Smith for the opportunity to guest edit this special issue of Girlhood Studies: An Interdisciplinary Journal. Developed out of a meeting with them at the inaugural International Girls Studies Association conference in Norwich (UK) in 2016, this collaboration has built on the promise of that important gathering and realized my own hopes expressed there, so I thank them both.

$\cos$

BARBARA JANE BRICKMAN is an Assistant Professor of Media and Gender Studies at the University of Alabama. Her work has appeared in Camera Obscura (2007), Discourse (2016), and Journal of Popular Music Studies (2016). Since the publication of her first book, New American Teenagers: The Lost Generation of Youth in 1970s Film (2012), she has written a volume on the film Grease for the Cinema and Youth Cultures series (2018) and is currently working on a manuscript on lesbian camp in American popular culture. She is also the founder and director of the Druid City Girls Media Camp in Tuscaloosa, AL. ORCID: https://orcid.org/ 0000-0002-3949-5245. Email: bjbrickman@ua.edu 


\section{Notes}

1. Ann Travers chooses to use gender neutral pronouns.

2. In Queer Girls, Temporality and Screen Media: Not "Just a Phase" (2016), Monaghan's focus is on this representation of queer girlhood as "just a phase."

\section{References}

Brickman, Barbara J. 2016. "This Charming Butch: The Male Pop Idol, Girl Fans, and Lesbian (in)Visibility.” Journal of Popular Music Studies 28: 443459. https://doi.10.1111.jpms.12193.

Brickman, Barbara J. 2018. Grease: Gender, Nostalgia and Youth Consumption in the Blockbuster Era. London: Routledge.

Driver, Susan. 2007. Queer Girls and Popular Culture: Reading, Resisting, and Creating Media. New York: Peter Lang.

Gonick, Marnina. 2006. "Sugar and Spice and Something More Than Nice?

Queer Girls and Transformations of Social Exclusion." In Girlhood: Redefining the Limits, ed. Yasmin Jiwani, Candis Steenbergen and Claudia Mitchell, 122137. Montreal: Black Rose Books.

Kearney, Mary Celeste. 2011. "Girls' Media Studies 2.0." In Mediated Girlhoods: New Explorations of Girls' Media Culture, ed. Mary Celeste Kearney, 1-14. New York: Peter Lang.

Kitchen Sisters. 2010. "The Day the Earth Stood Still.” The Hidden World of Girls, 3 June. http://www.kitchensisters.org/girlstories/the-series/the-day-theearth-stood-still/.

Monaghan, Whitney. 2016. Queer Girls, Temporality and Screen Media: Not "Just a Phase."London: Palgrave Macmillan.

Projansky, Sarah. 2014. Spectacular Girls: Media Fascination and Celebrity Culture. New York: New York University Press.

Stockton, Kathryn B. 2009. The Queer Child, or Growing Sideways in the Twentieth Century. Durham, NC: Duke University Press.

Travers, Ann. 2018. The Trans Generation: How Trans Kids (and Their Parents) Are Creating a Gender Revolution. New York: New York University Press.

\section{Discography}

Nelson, Davia, and Nikki Silva. "The Day the Earth Stood Still." The Hidden World of Girls, National Public Radio. Washington, DC: Morning Edition, 3 June 2010. 
